\title{
人種間の違いと人種内の違い一体内動態，薬効における遺伝子多型一
}

\author{
家 入一 郎, * 樋口駿

\section{Pharmacogenomics: Inter-ethnic and Intra-ethnic Differences in Pharmacokinetic and Pharmacodynamic Profiles of Clinically Relevant Drugs}

\author{
Ichiro IEIRI* and Shun HIGUCHI \\ Department of Clinical Pharmacokinetics, Graduate School of Pharmaceutical Sciences, \\ Kyushu University, 3-1-1 Maidashi, Higashi-ku, Fukuoka 812-8582, Japan
}

(Received October 10, 2008)

\begin{abstract}
Intra- and inter-ethnic differences in pharmacokinetic and pharmacodynamic profiles of clinically relevant drugs are important issues not only for scenes of appropriate drug use in clinical settings but also for those of the drug development. Pharmacogenomics is extremely useful for understanding these racial differences. In this presentation, I will introduce pharmacogenomic concepts (e.g., single nucleotide polymorphisms (SNPs) and haplotype) for interpretation of racial differences in some drugs; pharmacogenomics of drug transporters such as OATP1B1 (organic anion transporting-polypeptide 1B1) and OCT1 (organic cation transporter 1) in pravastatin, metformin, and rosuvastatin will be discussed as model drugs.
\end{abstract}

Key words — intra-ethnic; inter-ethnic; pharmacogenomics; pharmacokinetics; pharmacodynamics; clinically relevant drug

\section{1. はじめに}

医薬品の体内動態や効果には個人差（人種内の違 い）があるが，同様に人種間にも差が認められる. 近年，関連するタンパクをコードする遺伝子にみら れる変異がこれらの人種内や人種間の差の原因にな ることが明らかにされつつある。これらの差の理解 は，医薬品の適正使用のみならず医薬品の開発にと っても重要となる。ここでは，薬物の吸収や分布に 寄与する薬物輸送タンパク遺伝子多型に注目し，実 際に臨床で汎用される医薬品を取り上げ，体内動態 や効果にみる人種間，人種内の違いとの関連につい て考えてみたい.

\section{2. プラバスタチンと SLCO1B1 遺伝子多型}

HMG-CoA 還元酵素阻害剂（スタチン）である プラバスタチンは，経口投与後，肝臓に選択的に取 り込まれ，肝代謝を受けることなく，胆汁中へ排出 されたのち，体外へ排泄される。コレステロール合

九州大学大学院薬学研究院薬物動態学分野 ( $\bar{T} 812-$ 8582 福岡市東区馬出 3-1-1)

*e-mail: ieiri-ttr@umin.ac.jp

本総説は, 日本薬学会第 128 年会シンポジウム S33 で 発表したものを中心に記述したものである.
成阻害が主な作用機序であるが，そのためには，肝 取り込みが重要となる。肝細胞の血液側にほぼ特異 的に発現する OATP1B1 (organic anion transporting-polypeptide 1B1）はプラバスタチンをはじめと するほとんどすべてのスタチンの肝取り込みを担当 する. OATP1B1 をコードする $S L C O 1 B 1$ 遺伝子に はその輸送機能を変化させる変異の存在が知られて いる. その中で, $388 \mathrm{~A}>\mathrm{G}(130 \mathrm{Asn}>\mathrm{Asp})$ と $521 \mathrm{~T}$ $>\mathrm{G}$ (174Val >Ala）の 2 種類の一塩基置換（SNP: single nucleotide polymorphism) が重要であり，単 独で存在する場合, 輸送機能は前者で立進, 後者で 低下する（Fig. 1)。これらの変異は，実際にはハ プロタイプとして存在し，130Asn174Val（両箇所 とも野生型で変異がないアレル）を $S L C O 1 B 1^{*} 1 a$, 130Asp174Val（130 位のみに変異がある）を SLCO1BI ${ }^{*} 1 b, 130 \mathrm{Asn} 174 \mathrm{Ala}(174$ 位のみに変異が ある）を SLCOIBI*5, 130Asp174Ala（両箇所とも 変異体であるアレル）を $S L C O 1 B 1^{*} 15$ と国際命名 されている，日本人の場合，174Val $>$ Ala は*5 型 で存在することはなく，*15 で存在する（*17 が実 際は多いとされているが，ここでは*15に留め る)。相反する機能を持つ SNPs の組み合わせとな 


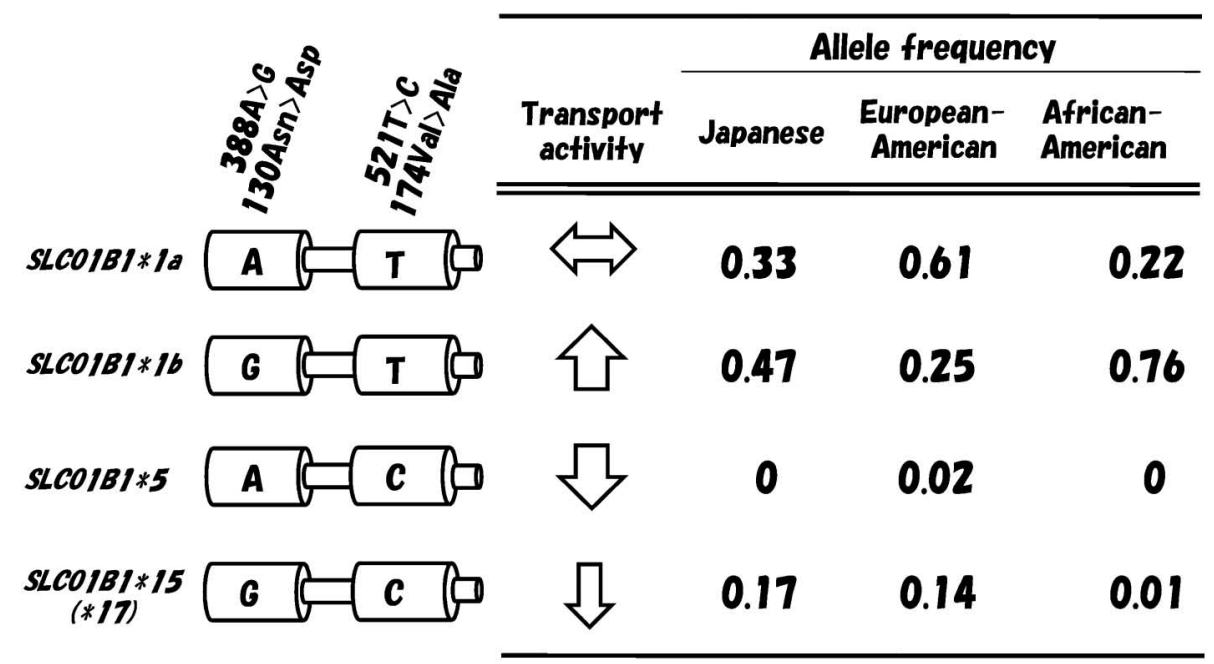

Fig. 1. Differences in Transport Activity of OATP1B1 among Four Important Haplotypes and Allelic Frequencies of SLCO1B1 among Three Ethnic Populations

るが，輸送機能は著しく低下する。 ${ }^{1)} 174 \mathrm{Val}>\mathrm{Ala}$ は輸送機能の欠損を伴う変異ではないが, 著しく低 下させることが分かる。 日本人での頻度は $15 \%$ 程 度であり, 高頻度にみられる．SLCO1B1*15 変異 がある場合, 多くのスタチンの肝臟への取り込みは 低下し, 中心静脈に流れ込むことから，血中濃度は 上昇する. ${ }^{1)}$ 一方, $S L C O 1 B 1^{*} 1 b$ では逆の現象が観 察される. ${ }^{2)}$

このような遺伝子型／表現型関連を念頭に置き, プラバスタチン体内動態にみる人種間の違いを考え てみたい. $40 \mathrm{mg}$ 単回投与後に得られる血中濃度に は人種差が観察され，African Americans（AA，黒 人）に比べ, European American（EA，白人）で 高值を示す (Fig. 2). ${ }^{1-3)}$ 血中濃度の上昇を招く $S L C O 1 B 1 * 5$ あるいは*15 アレルの頻度を比較する と（Fig. 1), 黒人での頻度は著しく低く, 一方で, 低い血中濃度の原因となる ${ }^{*} 1 \mathrm{~b}$ アレルの頻度は極 めて高い特徵がある. ${ }^{4)}$ これらの頻度の違いが白人 と黒人にみる体内動態の違いの大きな原因と考えら れる. 残念ながら, 日本人 (JP) での $40 \mathrm{mg}$ 単回 投与試験の報告がないため, 単純な比較は難しい が，変異の頻度をみると，174Val>Ala の頻度には JP と EA との間に差がないが, ハプロタイプの構 成に差がみられる。一方, 変異のない*1aアレルの EA での頻度は 3 人種間で最も高い.これらの違い が体内動態や人種差に与える影響は不明であるが, 興味深い。ただ，日本人では $10 \mathrm{mg}$ の低用量であ るにも係わらず比較的高い血中濃度推移が観察され

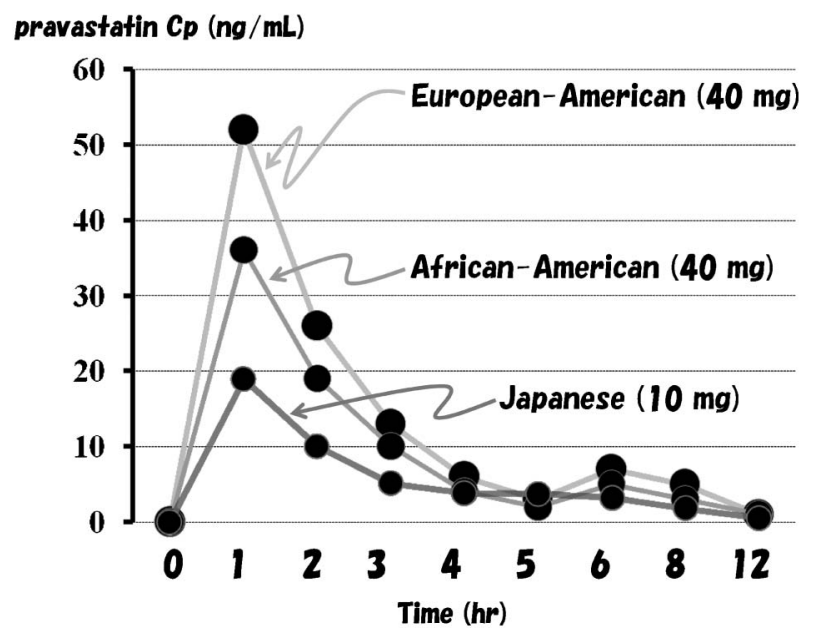

Fig. 2. Plasma Concentration Time Curves of Pravastatin in Three Ethnic Populations

ている.

\section{3.メトホルミンと $O C T 1$ 遺伝子多型}

ビグアナイド系糖尿病治療薬メトホルミンは 2 型 糖尿病の治療薬として汎用されるが，その血糖值コ ントロール作用に加え, 体重維持, 抗高脂血症作 用, 血管壁の保護などの作用も有することが大規模 臨床試験にて確認されて以来, 臨床での重要性が見 直されている. しかし, 臨床的な問題点としてノン レスポンダーの存在が指摘されている. メトホルミ ンにはいくつかの作用機序が指摘されているが, AMPK の活性化を介した肝での糖新生阻害が主と されている.したがって，肝への取り込みが薬効を 考える上で重要となる。メトホルミンは肝代謝され 
ることなく，肝に高発現する organic cation transporter 1 （OCT1）により肝へ取り込まれる. ${ }^{5)}$ 他の トランスポーター同様, コードする OCT1 遺伝子 には機能変化を伴う遺伝子変異が報告されている. 遺伝子変異，輸送活性，頻度を Table 1 にまとめ た。それらの中で， 61Arg >Cys， 401Gly > Ser, $420 \mathrm{Met}>$ deletion, $465 \mathrm{Gly}>\operatorname{Arg}$ の 4 種類の SNPs でヒトでの機能評価がなされており，興味深い．

Shu らは，これらの変異を有する健常成人と野生型 をホモ接合型で有する健常成人でのメトホルミン体 内動態の比較を行っている. $\left.{ }^{6}\right)$ その結果，変異体を 有する被検者で有意に高い血中濃度推移が観察され ている，AUC の有意な高値，CL/F の有意な低值 を示しており，これらの変異を有することで，肝へ の取り込みが低下することを示唆している. メトホ ルミンの効果の場は肝なので，肝取り込みの低下は 効果の減弱を招くことが予想される（スタチンと $S L C O 1 B 1$ 遺伝子多型でも同様なことが懸念され る)。そこで, Shu らは, 先の体内動態での検討と ほぼ同じ被検者を対象として糖負荷後の血糖值の変 化と遺伝子型との関連を評価している。7) 糖負荷 前，両群間には血糖値の時間推移には差はない。メ トホルミンの血糖降下作用は健常成人では直接みる ことができないため，メトホルミン服用後，糖負荷 を行い，血糖值の変化をみている，その結果，変異
がない群では，メトホルミン投与後，良好な血糖降 下作用がみられているのに対し，変異群での降下作 用には減弱が認められる。これらの 4 種類の変異に ついて遺伝子診断を行うことで，メトホルミンへの 反応の予測が可能になることが期待される。しか し，その頻度をみると，著しい人種差があることが 分かる (Table 1)。詳細な日本人での検討では，い ずれの変異の存在も確認されておらず，白人に特有 な変異とも言える. ${ }^{8)}$ メトホルミンのノンレンスポ ンダーの調査では，1) 空腹時血糖值 $<6.7 \mathrm{mmol} / 1$ をターゲットとした場合，2 型糖尿病患者の $38 \%$ に 十分な効果が得られない，2） 3 年治療後の成績（食 事療法併用）をみると, 目標空腹時血糖值 $<7.8$ $\mathrm{mmol} / \mathrm{l}(140 \mathrm{mg} / \mathrm{dl})$ 以下，あるいは HAlc $<7 \%$ を 達成する 2 型糖尿病患者の割合は約 4 割であると報 告されており，人種を問わずある一定の割合で存在 することが推定される．OCT1 遺伝子多型とメトホ ルミンによる血糖降下作用については，患者臨床試 験等での検証が必要となるが，日本人では，ノンレ スポンダーを $O C T 1$ 遺伝子多型からは説明でき ず，他の要因を探索する必要がある，頻度の違いで 人種差を論じることのできないケースである.

\section{4. ロスバスタチン体内動態と人種差}

ロスバスタチンの肝取り込みもプラバスタチン同 様 OATP1B1 により行われる.9 そ) そのため，遺伝子

Table 1. In vitro Function and Frequency of Variants in the OCTI Gene

\begin{tabular}{|c|c|c|c|c|c|c|c|}
\hline \multirow[b]{2}{*}{ Location } & \multirow{2}{*}{$\begin{array}{l}\text { Nucleotide } \\
\text { change }\end{array}$} & \multirow{2}{*}{$\begin{array}{c}\text { Protein } \\
\text { variation }\end{array}$} & \multicolumn{2}{|c|}{ Transport activity* } & \multicolumn{3}{|c|}{ Allele frequency $(\%)$} \\
\hline & & & $\mathrm{MPP}+$ & Metformin & $\begin{array}{c}\text { European Americans } \\
(n=200)\end{array}$ & $\begin{array}{c}\text { African Americans } \\
\qquad(n=200)\end{array}$ & $\begin{array}{l}\text { Japanese } \\
(n=116)\end{array}$ \\
\hline Exon 1 & $41 \mathrm{C}>\mathrm{T}$ & $\mathrm{S} 14 \mathrm{~F}$ & Increase & Decrease & 0.0 & 3.1 & 0.0 \\
\hline Exon 1 & $262 \mathrm{~T}>\mathrm{C}$ & $\mathrm{R} 61 \mathrm{C}$ & Decrease & Decrease & 7.2 & 0.0 & 0.0 \\
\hline Exon 2 & $480 \mathrm{C}>\mathrm{G}$ & F160L & Similar & Similar & 6.5 & 0.5 & 8.6 \\
\hline Exon 3 & $566 \mathrm{C}>\mathrm{T}$ & S189L & Similar & Decrease & 0.5 & 0.0 & 0.0 \\
\hline Exon 3 & $659 \mathrm{G}>\mathrm{T}$ & G220V & Decrease & Decrease & 0.0 & 0.5 & 0.0 \\
\hline Exon 6 & $1022 \mathrm{C}>\mathrm{T}$ & P341L & Decrease & Similar & 0.0 & 8.2 & 16.8 \\
\hline Exon 6 & $1025 \mathrm{G}>\mathrm{A}$ & $\mathrm{R} 342 \mathrm{H}$ & Similar & Similar & 0.0 & 3.1 & 0.0 \\
\hline Exon 7 & $1201 \mathrm{G}>\mathrm{A}$ & G401S & Decrease & Decrease & 1.1 & 0.7 & 0.0 \\
\hline Exon 7 & $1222 \mathrm{~A}>\mathrm{G}$ & M408V & Similar & Similar & 59.8 & 73.5 & 81.0 \\
\hline Exon 7 & 1256delATG & M420del & Similar & Decrease & 18.5 & 2.9 & 0.0 \\
\hline Exon 8 & $1320 \mathrm{G}>\mathrm{A}$ & M440I & Similar & nd & 0.0 & 0.5 & 0.0 \\
\hline Exon 8 & $1381 \mathrm{G}>\mathrm{A}$ & V461I & Similar & nd & 0.0 & 1.0 & 0.0 \\
\hline Exon 9 & $1393 G>A$ & G465R & Decrease & Decrease & 4.0 & 0.0 & 0.0 \\
\hline Exon 9 & $1463 \mathrm{G}>\mathrm{T}$ & $\mathrm{R} 488 \mathrm{M}$ & Similar & Similar & 0.0 & 5.0 & 0.0 \\
\hline
\end{tabular}

\footnotetext{
* transport activity compared with $O C T 1$ reference, MPP +: 1-methyl-4-phenylpyridinium, del: deletion, nd: no data.
} 
型により体内動態が異なる。. Figure 3 には，アジア 3 人種と白人でのロスバスタチン $40 \mathrm{mg}$ 単回投与後 の血中濃度推移を示す. ${ }^{10)}$ Figure 2 では最も血中濃 度の高かった白人が最も低い推移を示している。一 方，同じ東洋人であるが，3人種間にも違いがあ る.これら 4 人種の $S L C O 1 B 1$ 遺伝子型の頻度比較 を Fig. 4 に示す. 1,11) Asian-Indians（AI）に特徵が
みられる。まず，東洋人では稀な $S L C O 1 B 11^{*} 5$ アレ ルが頻度は低いが認められる点，血中濃度の上昇の 原因となる $174 \mathrm{Val}>\mathrm{Ala}$ の頻度が 4\%と極めて低い 点である。アジア 3 人種では AI の血中濃度推移が 最も低く $174 \mathrm{Val}>\mathrm{Ala}$ 変異の頻度との関連が一見 疑われるが，白人の $174 \mathrm{Val}>\mathrm{Ala}$ の頻度は $16 \%$ と 日本人とは変わらない。このことは，白人の血中濃

AUC (unadjusted for body weight) in 4 racial populations after a single $40-\mathrm{mg}$ dose of rosuvastatin

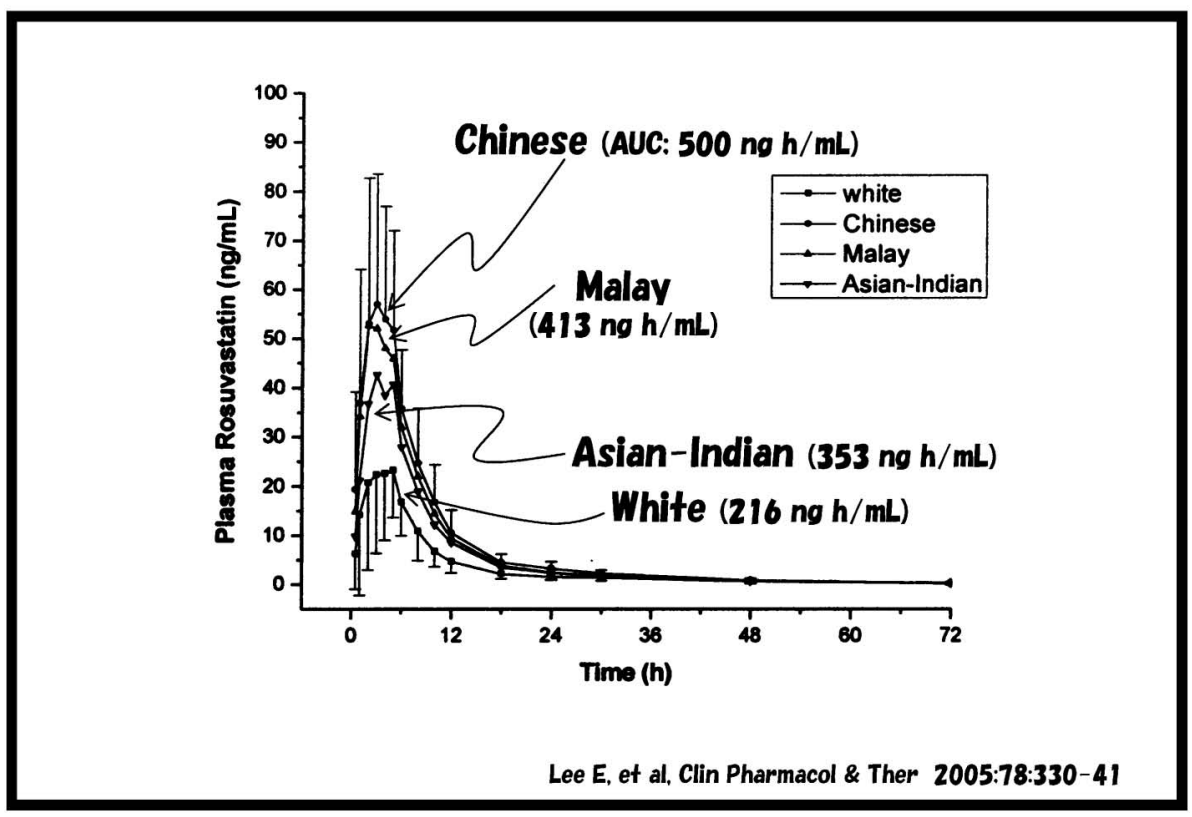

Fig. 3. Plasma Concentration Time Curves of Rosuvastatin in Four Ethnic Populations

Differences in allelic frequency of $S L C O 1 B /$ variants in 4 Asian populations

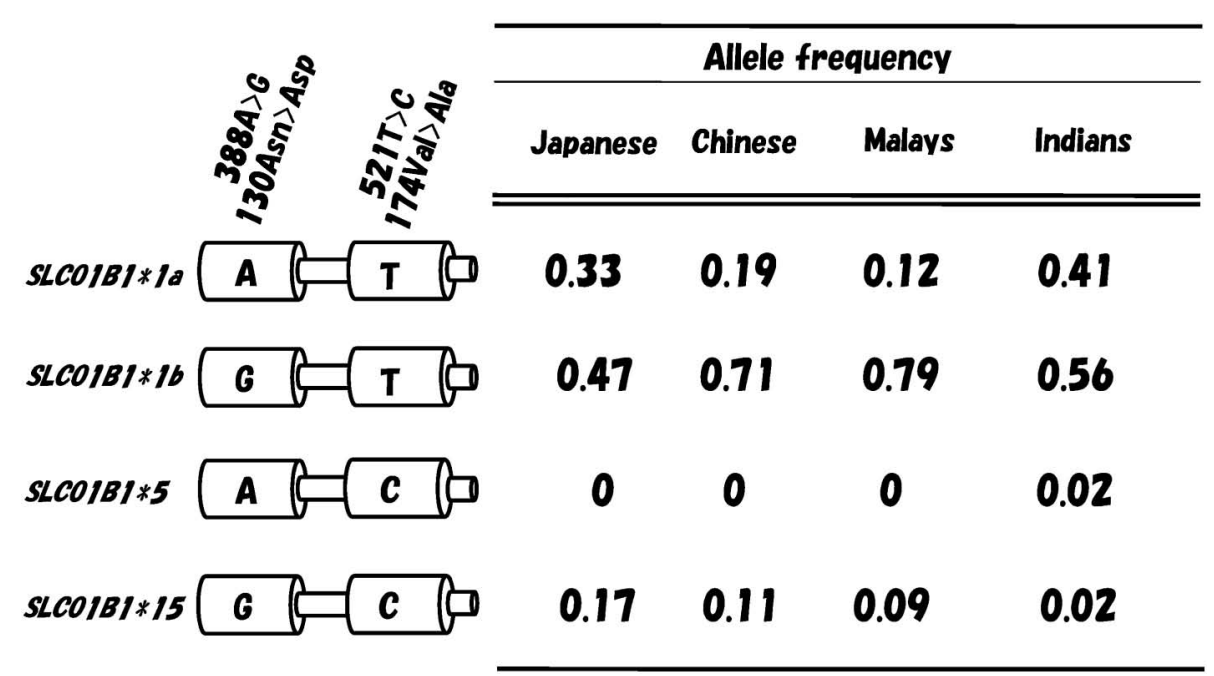

Fig. 4. Differences in Allelic Frequencies of SLCO1B1 Polymorphism among Four Ethnic Populations 
度が最も低值である現象と合わない。さらに， $S L C O 1 B 1^{*} 1 b$ アレルについてみると，その頻度は AI に比べて Chinese や Malays で高い. Chineseや Malays では低い血中濃度推移が予想されるが，実 際の結果は異なる。Lee ら10)の行った検討は被検 者の数が少ないので，再検討の余地もあろうかと思 われるが，Fig. 3 に示した人種間の違いを $S L C O 1 B 1$ 遺伝子多型から説明するのは難しい.

\section{5. シンポジウムで触れたその他の人種差に関す}

\section{る事項}

本シンポジウムで触れたその他の内容を参考文献 とともに箇条書きにする.

- rosuvastatin の体内動態にもSLCO1B1 遺伝子多 型が関与することを報告した研究であるが，韓国 人 $(\mathrm{K})$ と日本人間 $(\mathrm{JP})$ にも遺伝子型の頻度が異 なることを示している $\left[{ }^{*} 1 \mathrm{a} /{ }^{*} 15=3.5 \%(\mathrm{~K}) ; 11.7\right.$ $\%(\mathrm{JP}),{ }^{*} 1 \mathrm{~b} /{ }^{*} 1 \mathrm{~b}=33.5 \%(\mathrm{~K}) ; 21.7 \%$ (JP) ]. ${ }^{9)}$

・中国においては，Han 族が多数を占めるが，20 以上の少数民族が暮らす。 Dong 族や She 族間で 遺伝子変異の頻度の違いが報告されている. ${ }^{12)}$ 広 い国土であるので, 当然かもしれない.

6. おわりに

Pharmacogenomics が導入されて，体内動態や効 果にみる個人差（人種内の違いでもあろう）の原因 の解釈が一部可能となった。人種間の違いも同様で あろうが，メトホルミンやロスバスタチンで紹介し た事例は未解決である．特に薬効, pharmacodynamics の違いについては関与するタンパクが極めて 多いことから，難しい場合が多い。少なくとも， pharmacokineticsに関与するタンパクの機能変化も 含めた遺伝子多型情報だけは整備しておきたい.

\section{REFERENCES}

1) Nishizato Y., Ieiri I., Suzuki H., Kimura M., Kawabata K., Hirota T., Takane H., Irie S., Kusuhara H., Urasaki Y., Urae A., Higuchi S., Otsubo K., Sugiyama Y., Clin. Pharmacol. Ther., 73, 554-565 (2003).
2) Maeda K., Ieiri I., Yasuda K., Fujino A., Fujiwara H., Otsubo K., Hirano M., Watanabe T., Kitamura Y., Kusuhara H., Sugiyama Y., Clin. Pharmacol. Ther., 79, 427-439 (2006) .

3) Ho R. H., Choi L., Lee W., Mayo G., Schwarz U. I., Tirona R. G., Bailey D. G., Michael Stein C., Kim R. B., Pharmacogenet. Genomics., 17, 647-656 (2007).

4) Ieiri I., Takane H., Hirota T., Otsubo K., Higuchi S., Expert. Opin. Drug Metab. Toxicol., 651-674 (2006).

5) Takane H., Shikata E., Otsubo K., Higuchi S., Ieiri I., Pharmacogenomics, 9, 415-422 (2008).

6) Shu Y., Brown C., Castro R. A., Shi R. J., Lin E. T., Owen R. P., Sheardown S. A., Yue L., Burchard E. G., Brett C. M., Giacomini K. M., Clin. Pharmacol. Ther., 83, 273-280 (2008).

7) Shu Y., Sheardown S. A., Brown C., Owen R. P., Zhang S., Castro R. A., Ianculescu A. G., Yue L., Lo J. C., Burchard E. G., Brett C. M., Giacomini K. M., J. Clin. Invest., 117, 1422-1432 (2007).

8) Shikata E., Yamamoto R., Takane H., Shigemasa C., Ikeda T., Otsubo K., Ieiri I., J. Hum. Genet., 52, 117-122 (2007).

9) Choi J. H., Lee M. G., Cho J. Y., Lee J. E., Kim K. H., Park K., Clin. Pharmacol. Ther., 83, 251-257 (2008).

10) Lee E., Ryan S., Birmingham B., Zalikowski J., March R., Ambrose H., Moore R., Lee C., Chen Y., Schneck D., Clin. Pharmacol. Ther., 78, 330-341 (2005).

11) Jada S. R., Xiaochen S., Yan L. Y., Xiaoqiang X., Lal S., Zhou S. F., Ooi L. L., Chowbay B., Eur. J. Clin. Pharmacol., 63, 555-563 (2007).

12) Du J., Shi Y., Zhang A., Wang L., Xuan J., He G., Xu L., Xu M., Shu A., Yu L., Li X., Meng J., Feng G., Xing Q., He L., Pharmacogenomics, 8, 559-566 (2007). 